\title{
KEBIJAKAN PENANGKAPAN DAN PEMANFAATAN SUMBER DAYA IKAN LAUT-DALAM DI INDONESIA
}

\author{
Ali Suman ${ }^{1)}$ dan Badrudin ${ }^{2)}$ \\ 1) Peneliti pada Balai Riset Perikanan Laut, Muara Baru-Jakarta \\ 2) Peneliti pada Pusat Penelitian Pengelolaan Perikanan dan \\ Konservasi Sumber Daya Ikan, Ancol-Jakarta \\ Teregistrasi I tanggal: 8 Oktober 2010; Diterima setelah perbaikan tanggal: 19 Oktober 2010; \\ Disetujui terbit tanggal: 29 Oktober 2010
}

\begin{abstract}
ABSTRAK
Jenis-jenis organisme laut-dalam yang telah ditemukan antara lain meliputi ikan bertulang rawan (Elasmobranch), ikan bertulang keras (bony fish), krustasea, cephalopod, echinoids, asteroids, ophiuroids, holoturoids, dan anthozoa. Dari sejumlah 550 jenis biota laut, ada sebagian di antaranya bahkan belum ditemui dalam literatur. Jenis-jenis ikan laut-dalam yang ditemui di Samudera Hindia tampaknya mempunyai prospek yang cukup baik untuk dimanfaatkan. Sebagian besar jenis-jenis ikan laut-dalam memiliki karakterisitik daging yang khusus dengan kandungan protein yang tinggi dan kandungan lemak yang rendah. Selain itu juga dalam daging ikan laut-dalam tersebut telah ditemukan 17 jenis asam amino, yaitu sembilan asam amino esensial dan sisanya asam amino non esensial yang ke semuanya itu dibutuhkan oleh tubuh manusia. Dari 10 jenis ikan laut-dalam yang dianalisis tempak bahwa leusin merupakan asam amino esensial dengan kuantias paling dominan. Selain asam amino, dalam daging ikan laut-dalam juga ditemukan unsur kimia steroid yaitu sejenis hormon yang berisi nucleolus steroid, merupakan unsur biokimia yang berfungsi sebagai bahan pemulih vitalitas (aphrodisiach), yang berguna dalam meningkatkan kesehatan fungsi seksual. Dari manfaat kandungan biokimia ikan laut-dalam tersebut kiranya perlu direkomendasikan agar eksploitasi sumber daya ikan laut dalam hendaknya tidak ditujukan untuk konsumsi langsung. Pemanfaatan yang optimal hendaknya ditujukan untuk memperoleh kandungan bioaktif bagi keperluan farmakologis. Dengan demikian, stok ikan laut-dalam yang tidak terlalu besar tersebut dapat dimanfaatkan secara berkelanjutan dalam jangka waktu yang panjang.
\end{abstract}

KATAKUNCI: ikan laut-dalam, eksploitasi, pemanfaatan, Samudera Hindia

ABSTRACT: Deep-sea fish resources exploitation and utilization in Indonesia. By: Ali Suman and Badrudin

A wide range of marine organisms had been found in the catch. These include fishes group of both bony fish and Elasmobranch. Other groups were crustaceans, cephalopods, echinoids, asteroids, ophiuroids, holoturoids, and anthozoa. A total of more than 550 species were found in the catch, of which until now some species were not yet found in the literatures. Most of deepsea fish in the Eastern Indian Ocean having special meat characteristic with high protein content and lower lipid. On top of that there are some 17 amino acid, consisted of 9 essential and non essential were found in the dee-sea flesh, all needed for metabolism of human life. From the flesh analysis of 10 deepsea species it was found that leusin provide the highest content of the essential amino acid. In addition to the 


\begin{abstract}
amino acid content it was also found steroid, abiochemical substant containing nucleolus steroid that provide agent in accelerating sexual health function. From this benefit of biochemical substant it is recommended that deep-sea fish resources exploitation should not allotted toward direct consumption. Some optimal exploitation of these resources should be directed to obtain bioactive substants for pharmalogical purposes, so that the relatively small size of potential stock biomass could be utilized sustainably.
\end{abstract}

KEYWORDS: deep-sea fish, exploitation, utilization, Indian Ocean

\section{PENDAHULUAN}

Kawasan laut-dalam adalah lokasi perairan pada kedalaman lebih dari $200 \mathrm{~m}$ yang pada umumnya merupakan kawasan perairan di bawah daerah yufotik. Beberapa jenis ikan tertentu yang jarang sering dicari di pasaran. Di Europa, ikan laut-dalam lunglip dipasarkan sebagai cusk eel, sejenis belut. Di New Zealand, ikan tersebut disebut hung, di Amerika Latin disebut cangrio dan Jepang disebut kingu. Ikan tersebut dipasarkan secara eceran dan dapat ditemui di restoran dalam bentuk tertentu dengan tekstur daging yang unik. Di Australia ikan alfonsino (Beryx splendens) telah dimanfaatkan secara intensif dan telah hampir over fishing. Sejumlah besar jenisjenis organisme laut telah ditemukan dalam hasil tangkapan, seperti ikan bertulang rawan (Elasmobranch), bertulang keras (bony fish), krustasea, cephalopod, echinoids, asteroids, ophiuroids, holoturoids, dan anthozoa. Dari sejumlah 550 jenis biota laut, ada sebagian di antaranya bahkan belum ditemui dalam literatur (Anonymous, 2006). Analisis selanjutnya hanya akan dibatasi kepada sumber daya ikan dan jenis-jenis ikan.

Laju tangkap yang setara dengan catch per unit of effort, merupakan salah satu indeks kelimpahan stok sumber daya ikan. Fluktuasi laju tangkap dapat diasumsikan sebagai respons komunitas ikan terhadap faktor-faktor yang mempengaruhi, baik yang bersifat internal atau eksternal. Dalam perikanan yang dieksploitasi, terutama di perairan laut yang relatif dangkal, tekanan penanggkapan merupakan faktor yang paling berpengaruh. Faktor-faktor apa yang paling berpengaruh terhadap eksistensi sumber daya ikan di laut-dalam, sampai saat ini belum diketahui. Sebagaimana telah dikatakan terdahulu bahwa status sumber daya ikan laut-dalam sampai saat ini dapat dikatakan belum terjamah, sebagaimana halnya sumber daya ikan yang ada di kawasan perairan slope dan seamounts di perairan antara Laut Banda dan Laut Arafura (Badrudin et al., 2005). Dengan demikian, tersedianya data dan informasi tentang laju tangkap sumber daya ikan di suatu perairan baik secara spatial atau temporal merupakan aspek penting yang diperlukan bagi pengembangan dan pemanfaatannya.

\section{Laju Tangkap dan Kepadatan Stok}

Berdasarkan atas data laju tangkap sumber daya ikan laut-dalam (Badrudin et al., 2007; Badrudin et al., 2007a; Suprapto \& Badrudin 2006) di Samudera Hindia barat Sumatera dan selatan Jawa, melalui suatu prosedur penghitungan dan asumsi-asumsi dapat diestimasi besarnya kepadatan stok (stock density, Shindo, 1973), biomassa (standing stock, Saeger et al., 1976) dan potensi (potential yield, Gulland, 1983).

Di perairan selatan Jawa, laju tangkap minimum 8,7 kg/jam diperoleh pada daerah kedalaman 500-750 m dan laju tangkap maksimum 2.075,6 kg/jam diperoleh pada daerah kedalaman 750-1.000 m. Rata-rata laju tangkap pada ketiga daerah kedalaman 
$<500 \mathrm{~m}$, 500-750 m, dan 750-1.000 m masing-masing berturut-turut 311,$8 ; 81,3$; dan $410,9 \mathrm{~kg} / \mathrm{jam}$, dengan rata-rata keseluruhan sekitar 257,0 kg/jam. Estimasi kepadatan stok di perairan selatan Jawa di kawasan perairan yang dapat di-trawl (trawable ground) terendah sekitar 1,8-7,3 ton/ $\mathrm{km}^{2}$. Dengan mengacu kepada kawasan yang dapat di-trawl yang sebenarnya relatif sempit dibandingkan dengan luasnya perairan selatan Jawa, diperoleh estimasi biomassa ikan lautdalam 50.250 ton (Lampiran Tabel 1 dan 2).

Di perairan tenggara Enggano, baik laju tangkap minimum $5,5 \mathrm{~kg} / \mathrm{jam}$ dan laju tangkap maksimum sekitar 330,1 kg/jam yang tampak lebih rendah, keduanya diperoleh pada daerah kedalaman 500-750 $\mathrm{m}$. Dugaan kepadatan stok di perairan tenggara Enggano bervariasi mulai yang rendah sekitar 0,6-0,8 ton $/ \mathrm{km}^{2}$ sampai yang tinggi antara 3,3-9,9 ton $/ \mathrm{km}^{2}$, dengan ratarata sekitar 2,3-3,8 ton $/ \mathrm{km}^{2}$. Berdasarkan atas angka-angka tersebut, dugaan besarnya biomassa (standing stock) sekitar 3.176 ton.

Karena jumlah pengambilan contoh penangkapan di perairan barat Bengkulu yang relatif terbatas yaitu hanya meliputi dua daerah kedalaman, 500-750 m dan 750$1.000 \mathrm{~m}$. Laju tangkap minimum masingmasing 7,5 dan $17,5 \mathrm{~kg} / \mathrm{jam}$, dan laju tangkap maksimumnya 18,1 dan $20,5 \mathrm{~kg} /$ jam sedangkan rata-ratanya 12,8 dan 19,0 $\mathrm{kg} / \mathrm{jam}$. Dugaan rata-rata kepadatan stoknya berada pada kisaran antara 0,4-0,6 ton $/ \mathrm{km}^{2}$ dengan total biomassa hanya sekitar 62,5 ton.

Laju tangkap minimum di perairan barat Laut Simeuleu 3,3 kg/jam terjadi pada daerah kedalaman 751-1.000 m, sedangkan laju tangkap maksimum 90,1 kg/jam terjadi pada daerah kedalaman 500-750 m. Kisaran kepadatan stok tampak lebih lebar.
Kepadatan stok minimum antara 0,08-0,24 ton $/ \mathrm{km}^{2}$ dan maksimum antara 2,4-2,7 ton/ $\mathrm{km}^{2}$. Dugaan total biomassa di perairan tersebut sekitar 4.827 (4.800) ton.

Di perairan sebelah barat Banda Aceh, laju tangkap terendah $8,4 \mathrm{~kg} / \mathrm{jam}$, ditemukan pada daerah kedalaman $<500 \mathrm{~m}$, sedangkan laju tangkap tertinggi $110,0 \mathrm{~kg} /$ jam terdapat pada daerah kedalaman $500-$ $750 \mathrm{~m}$. Biomassa total dari kawasan perairan lepas pantai Banda Aceh ini sekitar 4.491 (4.500) ton.

Hasil penelitian Rusia di Samudera Pasifik tropis dan lautan di sekitar Kepulauan Indo-Australia menunjukan adanya sejumlah besar ikan mesopelagis. Biomassa kelompok ikan tersebut telah diestimasi pada kolom air sampai $1.000 \mathrm{~m}$. Kepadatan ikan di daerah Kuroshio pada waktu itu sekitar $5,0-6,0 \mathrm{mg} / \mathrm{m}^{3}$, perairan ekuatorial antara 3,1-8,1 mg/m $\mathrm{m}^{3}$, dan massa air bagian tengah antara $0,6-2,0 \mathrm{mg} / \mathrm{m}^{3}$. Penelitiannya itu terbatas kepada fauna ikan bathypelagis. Pada kolom air 1.000-4.000 $\mathrm{m}$, biomassa ikan yang sama adalah sekitar satu per sepuluh bagi besarnya ikan mesopelagis. Walaupun hasil tersebut tidak dapat secara langsung dibandingkan dengan hasil penelitian ini karena adanya perbedaan dalam pengukuran, estimasi kelompok ikan demersal di sebelah barat perairan Atlantik Utara telah dikatakan oleh Heidrich \& Rowe pada tahun 1977 (Marshall, 1979). Berdasarkan atas hasil pengambilan contoh penangkapan dengan trawl 116 stasiun yang dipantau dengan dua pasang kamera, kepadatan stok ikan dasar yang dikatakan dalam bobot per meter persegi sepanjang kawasan antara 497-2.780 m, bervariasi antara 0,63-5,78 g/ $/ \mathrm{m}^{2}$ (Marshall, 1979). Besaran tersebut sama dengan $6,3-$ 57,8 ton $/ \mathrm{km}^{2}$. Dibandingkan dengan kepadatan stok ikan laut-dalam di bagian lautan di permukaan bumi ini, kepadatan stok di perairan barat Sumatera yang 
merupakan bagian dari Samudera Hindia tampak lebih rendah dibandingkan dengan kepadatan stok di perairan Atlantik Utara.

Dari hasil uji-coba penangkapan dengan rawai dasar di perairan Teluk Semangka, Lampung, tertangkap tiga jenis ikan demersal laut-dalam yang tidak pernah tertangkap di bagian manapun dari perairan Selat Sunda sebelumnya. Jenis ikan tersebut adalah Gepyroberix darwini family Trachichthyidae, Peristedion sp., dari famili Triglidae dan satu jenis dari famili Macrouridae. Warna badan dari kedua jenis ikan tersebut merah cerah. Diperoleh informasi bahwa di Jepang, Gepyroberix darwini sudah merupakan ikan konsumsi yang umum.

\section{Keanekaragaman Hayati}

Keanekaragaman biologi atau biodiversity adalah keanekaragaman dari mahluk hidup. Makin besar keragaman jenis-jenis hewan maka keanekaragamannya makin tinggi. Banyaknya jenis hewan dan jumlah individu dari satu jenis hewan tersebut digunakan untuk memperkirakan besarnya indeks keanekaragaman hayatinya. Keanekaragaman hayati bervariasi sesuai dengan lokasi, habitat, musim, dan beberapa faktor lain termasuk juga metode pengitungannya (Ludwig \& Reynold, 1988; Badrudin et al., 2006).

Dari analisis keanekaragaman jenis ikan tampak bahwa pada kisaran kedalaman 250-1.000 m di perairan tenggara Enggano, terdapat suatu fenomena makin tinggi kedalaman perairan jumlah jenis ikan makin bertambah, atau terdapat kecenderungan jumlah jenis ikan makin banyak, sebagaimana tercermin dari indeks kekayaan (Richness index). Namun demikian indeks keanekaragamannya (Shannon index), menurun sejalan dengan kedalaman perairan. Indeks yang tertinggi, $\mathrm{H}=2.171$, termasuk pada kelompok rendah sampai sedang, terjadi pada daerah kedalaman $<500$ m. Dari nilai Indeks Simpson tampak bahwa tiga kelompok ikan yang dominan adalah famili Macrouridae, Melanonidae, dan Ophidiidae. Jenis yang terbanyak dari famili Macrouridae adalah Caelorinchus divergens dan jenis lainnya Caelorinchus sp., Gadamus colletti, Ventrifossa sp., Nezumia sp., Nezumia sp., dan Pseudonezumia japonica.

Jenis ikan yang paling melimpah di perairan lepas pantai Bengkulu pada kedua daerah kedalaman diwakili oleh famili Macrouridae, jenis Caelorinchus divergens. Jenis ikan benthopelagic ini diduga atau tampaknya selain memiliki kisaran sebaran kedalaman yang lebih lebar atau habitat dasar perairan barat Bengkulu ini relatif serupa.

Nilai indeks keanekaragaman Simpson perairan Barat Laut Simeuleu tampak konsisten dengan indeks Kekayaan, di mana makin besar nilai indeks Simpson, makin rendah keanekaragaman. Implikasi dari fenomena tersebut adalah bahwa komunitas sumber daya ikan pada daerah kedalaman tersebut didominansi oleh hanya beberapa jenis ikan. Jenis ikan yang paling melimpah hanya satu jenis, yaitu Ostracoberyx dorgenys famili Ostracoberycidae. Lima jenis ikan yang paling melimpah pada daerah kedalaman adalah spinyfins, Diretmoides pauciradiatus (Diretmidae), Macrourid, Caelorinchus divergens, Alfonsinos, Beryx splendens, Ophidiid, Glyptophidium sp., dan ikan abangan Hoplostethus crassispinus dari famili Trachichthyidae (Badrudin et al., 2007; Badrudin et al., 2007a). Jenis ikan tersebut serupa dengan jenis ikan yang di Australia selatan dikenal sebagai orange roughy, $H$. atlanticus in the Southern Australia (Anonymous, 1992). 
Di perairan lepas pantai barat Banda Aceh indeks keanekaragaman, $\mathrm{H}=1,8$ dengan jenis ikan yang paling melimpah adalah Mycthopid, Diaphus sp., di mana jumlah individunya mencapai $92 \%$ dari jumlah keseluruhan individu ikan laut dalam yang tercatat. Jenis kedua yang cukup melimpah adalah Phosichtyds, Polymytme elongatus, kemudian ikan mata hijau, Chlorophthalmus sp. (Chloropthalmidae). Sebagaimana halnya dengan perairan Simeuleu, di mana Spinyfins, Diretmoides pauciradiatus merupakan jenis ikan paling melimpah, di perairan lepas pantai barat Banda Aceh jenis ikan tersebut merupakan ikan yang paling melimpah pada perairan yang lebih dalam. Berdasarkan atas fenomea tersebut diduga bahwa ikan Spinyfins merupakan penghuni utama laut dalam di perairan Samudera Hindia bagian timur.

Jenis-jenis ikan laut dalam yang ditemui di Samudera Hindia tampaknya mempunyai prospek yang cukup baik untuk dimanfaatkan. Namun pemanfaatan sumber daya ikan tersebut hendaknya tidak ditujukan untuk konsumsi langsung. Hal ini disebabkan karena sebagian besar jenisjenis ikan laut-dalam tersebut memiliki karakterisitik daging yang khusus dengan kandungan protein yang tinggi dan kandungan lemak yang rendah. Hal ini terbukti dari hasil analisis daging dari 10 jenis ikan laut-dalam, yaitu Dietmoides pauciradiatus, Benthodesmus tenuis, Beryx splendens, Hoplosthethus crassipinus, Hoplothethus sp., Ophidiidae, Ostracoberyx dorygenis, Godamus colleti, Myctophidae sp., dan Hyteroglypne japonica.

Selain itu juga dalam daging ikan lautdalam tersebut telah ditemukan 17 jenis asam amino, yaitu sembilan asam amino esensial dan sisanya asam amino non esensial yang kesemuanya itu dibutuhkan oleh tubuh manusia. Sebagai contoh jenis ikan Diretmoides pauciradiatus dan Hoplothethus crassispinus mengandung asam amino yang tertinggi dalam bentuk leusin dan prolin. Benthodesmus tenuis dan Beryx splanden mempunyai kandungan asam amino esensial yang tertinggi dalam bentuk leusin dan phenilalanin, demikian juga halnya dengan Holoplethus sp., Myctophidae sp., dan Hyteroglypne japonica, sedangkan Ophidiidae dan Ostracoberyu dorygenis kandungan tertinggi asam amino dalam bentuk glutamat dan leusin (Suseno et al., 2006).

Dari ke semua jenis ikan laut-dalam yang dianalisis tempak bahwa leusin merupakan asam amino esensial dengan kuantias paling dominan yang ditemukan pada daging ikan laut-dalam. Leusin adalah asam amino esensial yang termasuk ketogenik yang memproduksi keton dalam jantung. Asam amino yang termasuk katagori tersebut adalah lysin dan tripthopan. Asam amino adalah komponen biokimia yang penting yang diperlukan tubuh untuk memproduksi energi lalu merangsang bagian atas otak. Arginin dapat berperan sebagai aprodisiach juga ditemukan dalam kuantitas yang banyak yang mempunyai fungsi untuk memulihkan vitalitas atau obat kuat. Arginin dengan enzyme nitrogin oxidase mempunyai peran dalam memperlebar pembuluh darah. Selain asam amino, dalam daging ikan laut-dalam juga ditemukan unsur kimia steroid. Steroid adalah sejenis hormon yang berisi nucleolus steroid, yang merupakan bahan biokimia yang dapat berfungsi sebagai bahan pemulih vitalitas (aphrodisiach). Sebagaimana diketahuni bahwa aphrodisiach suatu unsur biokimia yang berguna dalam meningkatkan kesehatan fungsi seksual.

Dari manfaat kandungan biokimia ikan laut-dalam tersebut kiranya perlu direkomendasikan agar eksploitasi sumber 
daya ikan laut-dalam hendaknya tidak ditujukan untuk konsumsi langsung, sebagaimana halnya dengan pemanfaatan jenis-jenis ikan laut dangkal. Pemanfaatan yang optimal hendaknya ditujukan untuk memperoleh kandungan bioaktif bagi keperluan farmakologis. Dengan demikian, stok ikan laut-dalam yang tidak terlalu besar tersebut dapat dimanfaatkan secara berkelanjutan dalam jangka waktu yang panjang.

Secara umum, dapat dikatakan bahwa eksplorasi penangkapan ikan demersal laut-dalam dengan trawl dewasa ini dan pada saat mendatang hendaknya dianggap sebagai suatu kegiatan ilmiah dan bukan mencari sumber daya ikan inkonvensional untuk konsumsi. Sebagaimana diketahui bahwa beberapa aspek lingkungan lautdalam seperti tekanan kolom air yang sangat tinggi dan sangat sedikitnya makanan (ikan) telah menyebabkan jenis ikan laut-dalam mempunyai ketahanan yang tinggi dalam mempertahankan kelangsungan hidupnya. Aspek biologi yang sangat menarik adalah unsur-unsur kimia dari daging ikan tersebut seperti protein, lemak, dan unsur biokimia lainnya akan memerlukan analisis laboraturium dan penelitian lebih lanjut. Pada suatu cruise penelitian pernah terjadi di mana para anak buah kapal dan peneliti tidak dapat tidur semalam suntuk setelah mengkonsumsi daging ikan hitam (Bajacalifornia erimorensis) yang diolah secara dikukus. Pengalaman tersebut tentunya sangat penting bagi penelitian rintisan yang dilakukan dalam rangka pemanfaatan keanekaragaman sumber daya hayati.

\section{KESIMPULAN}

1. Dengan mengacu kepada kawasan yang dapat di trawl yang sebenarnya relatif sempit dibandingkan dengan luasnya perairan selatan Jawa, diperoleh estimasi biomassa ikan laut-dalam 50.250 ton. Di sepanjang barat Sumatera dengan tawling ground yang lebih sempit diperoleh dugaan biomassa sekitar 12.500 ton yang tersebar mulai dari tenggara Enggano ke utara sampai barat Banda Aceh.

2. Keanekaragaman hayati diduga bervariasi sesuai dengan lokasi, habitat, musim dan beberapa faktor lain. Dari analisis keanekaragaman jenis ikan tampak bahwa indeks yang tertinggi, $\mathrm{H}=2.171$ atau termasuk pada kelompok rendah sampai sedang.

3. Dari 10 jenis ikan laut-dalam yang dianalisis tempak bahwa leusin merupakan asam amino esensial dengan kuantias paling dominan. Selain asam amino, dalam daging ikan lautdalam juga ditemukan unsur kimia steroid yaitu sejenis hormon yang berisi nucleolus steroid, suatu unsur biokimia yang berfungsi sebagai bahan pemulih vitalitas, yang berguna dalam meningkatkan kesehatan fungsi seksual.

4. Dari manfaat kandungan biokimia ikan laut-dalam dan biomassa yang tidak terlalu besar tersebut perlu direkomendasikan agar eksploitasi sumber daya ikan laut dalam hendaknya tidak ditujukan untuk konsumsi langsung, tapi ditujukan untuk memperoleh kandungan bioaktif bagi keperluan farmakologis. Dengan demikian, stok ikan laut dalam yang tidak terlalu besar tersebut dapat dimanfaatkan secara berkelanjutan dalam jangka waktu yang panjang. 


\section{DAFTAR PUSTAKA}

Anonymous. 1992. Background Fisheries Statistics. DPIE. Canberra. Australia. August 1992. Issu Number 6. 47 pp.

Anonymous. 2006. The Japan-Indonesia deep sea fishery resources joint exploration project. Final Report. Overseas Fishery Cooperation Foundation. Japan-Agency for Marine and Fisheries Research. Ministry of Marine Affairs and Fisheries. Indonesia. 154+58 Figures and Plates.

Badrudin, A. Suman, \& Awwaludin. 2007. Size distribution and maturity of the slimeheads (Hoplostethus crassispinus) in the deep waters around Simeuleu Island, Western Sumatera, Eastern Indian Ocean. Indonesian Fisheries Research Journal. 13 (1): 9-16.

Badrudin, D. Nugroho, \&A. Suman. 2007a. The most abundance and the very rare deep sea species in the Western Sumatera, Eastern Indian Ocean. Indonesian Fisheries Research Journal. AMFR. MMAF. 13 (1): 17-30.

Badrudin, Wudianto, N. N. Wiadnyana, \& S. Nurhakim. 2006. Deep sea fish resources diversity and potential in the waters of western Sumatera of the Eastern Indian Ocean. Indonesian Fisheries Research Journal. AMFR. MMAF. 12 (2):113-127.

Badrudin, N. N. Wiadnyana, \& B. Wibowo. 2005. Deep water exploratory bottom long lining in the waters of the Arafura Sea. Indonesian Fisheries Research Journal. AMFR. MMAF. 11 (1): 41-46.
Gulland, J. A. 1983. Fish stock assessment. A Manual of Basic Methods. Vol.1. Food and Agriculture Organization Wiley series on Food and Agriculture. John Wiley \& Sons. 223 pp.

Ludwig, J. A. \& J. F. Reynolds. 1988. Statistical Ecology. A Primer on Methods and Computing. John Wiley \& Sons. New York. 337 pp.

Marshall, N. B. 1979. Development of Deep Sea Biology. Blandford Press. Dorset. U. K. 565 pp.

Shindo, S. 1973. General review of the trawl fishery and the demersal fish stock of the South China Sea. FAO Fish.Tech.Pap. 120. 49 pp.

Saeger, J., P. Martosubroto, \& D. Pauly. 1976. First report of the IndonesianGerman demersal fisheries project (Results of a trawl survey in the Sunda Shelf areas). Special Report. Contrib. of the Dem. Fish. Project. No.1. Mar. Fish. Res.Inst. Jakarta. 46 pp.

Suprapto \& Badrudin. 2006. Stock abundance index, density, composition, and distribution of deep sea shark and ray resources in the eastern Indian Ocean. Indonesian Fisheries Research Journal. AMFR. MMAF. 12 (1): 27-36.

Suseno, S. H., A. Suman, Wudianto, \& A. Damayanti. 2006. Nutrient and steroid contents of some deep sea fish from the waters of western Sumatera, Eastern Indian Ocean. Indonesian Fisheries Research Journal. AMFR. 12 (1). 